\title{
ADDIE Model In Teaching Module Design Process Using Modular Method: Applied Topics in Design And Technology Subjects
}

\author{
Zamri Sahaat $^{1 *}$, Nurfaradilla Mohamad Nasri ${ }^{1}$, Abu Yazid Abu Bakar ${ }^{1}$ \\ ${ }^{I}$ Faculty of Education, Universiti Kebangsaan Malaysia, 43600 Bangi, Selangor, Malaysia \\ "Corresponding author. Email: zamrismksgtapang@gmail.com
}

\begin{abstract}
Modular teaching modules are one of the practical pedagogical methods that can be used in the process of delivering knowledge and skills. Hence, the design of this modular teaching module should be carefully and systematically developed. This paper which examines the process of designing teaching modules using a modular approach based on the ADDIE model, aims to detail the use of the ADDIE model in designing modular modules for the applied topics of the design and technology. The ADDIE model was chosen mainly because of its conceptual framework that is relevant to the standard of learning and the standard of Design and Technology subjects. ADDIE's five-phase model of analysis, design, development, implementation, and evaluation can potentially be used to produce a modular teaching module that is good for teaching the applied topics in the Design and Technology subject. Based on this close and critical examination of the ADDIE model, a modular teaching module will be developed subsequently in order to achieve the ultimate goal of Design and Technology subject.
\end{abstract}

Keywords: ADDIE model, analysis, design, development, implementation, evaluation, modular

\section{INTRODUCTION}

The effectiveness of teaching in the classroom relies on the selection of suitable teaching and learning strategies. Nicholls and Nicholls (1978) defined curriculum as the learning opportunity designed by the teachers for their students. Therefore, to ensure that teaching objectives are achieved, lesson plans, teaching content, and hands-on activities need to be wisely arranged by the teacher.

Various teaching and learning models have been developed by researchers to meet the needs and the suitability of particularly subjects based on numerous teaching and learning theories such as behaviourism, cognitivism, constructivism, socio-constructivism, social, humanist, and etc. Based on the suggested models, diverse selections of teaching methods were designed to assist teachers in delivering the subject-content knowledge at school level. Among the increasingly popular pedagogical methods are contextual learning, critique and creative thinking approach, mastery learning, inquiry-based teaching, smart pedagogy, modular teaching approach, and 21st century teaching and learning approach.

In Malaysia, the modular curriculum and the modular teaching approach was initially introduced by the Ministry of Education in 2010. The modular curriculum is defined as a set of content compiled in small units of distinctive and complete fields, titles, skills, or grades (MOE Curriculum Development Section, 2010). While modular teaching approach focuses on task-based approach that is based on the building of skills and knowledge in discrete units. A point to note, the concept of modular approach introduced by the curriculum development team in Malaysia is a hybrid version of linear and non-linear approach.

In this paper, the module development theory that is intended to be applied and explored is the use of the ADDIE model in developing modular teaching modules for Design and Technology subject, or in Malay Language, Rekabentuk Teknologi (RBT). This RBT subject is the compulsory subject for Form 1 to Form 3 students in high school. The topics in this RBT subject are categorized into two areas, namely theory topics and applied topics. There are nine applied topics that students need to learn over the course of three years with fractions, two applied topics in Form 1, six applied topics in Form 2, and one applied topic in Form 3. All these applied topics require students to produce a project at the end of the learning week. Hence, nine projects need to be completed by the students.

The time allocated for teaching the applied topic is only 10 to 14 hours per topic per year. During that period, teachers are left alone to plan appropriate teaching strategies to deliver the subject-content 
knowledge, facts, design analysis, product sketches, and construction before product evaluations can be executed. Mia Bullock (2015) notes that the criteria of a good and effective teacher are posing extensive knowledge about that particular subject, able to strategies and plan his or her teaching time according to the schedule and using the latest technology to attract the attention of the students. Meanwhile, the Stenhouse model (1975) found that the success of curriculum implementation depends largely on the skills of the teacher to plan and implement teaching activities. According to the Stenhouse model (1975), teachers need to assess students' understanding from time to and the students' ability to apply the knowledge in various context so that teachers are better informed about the time needed for meaningful and effective learning. Therefore, based on Stenhouse model (1975), it is recommended that teaching strategies need to be more flexible and easily modified to fit the students' diverse need.

The ADDIE model is seen as one of the most suitable and practical teaching and learning model for the purpose of developing modular teaching modules for RBT subject. This model is aimed at assisting the development of a modular module that can perfectly fit with the content of RBT subject. Hence, this study will focus on the process of designing a modular teaching module for Design and Technology subjects using ADDIE model.

\section{RBT DOMAINS AND ADDIE MODEL}

There are various types of instructional design models that use their own strategies to achieve the selected objectives. The cognitive-constructivist learning model is the main reference and primary framework used in developing modular learning methods for RBT subjects. Instructional design refers to a systematic strategy, methodology and technology implemented to enable students to master the desired learning objectives (Yusup Hashim, 2006). The four main learning domains that needed to be achieved by students for RBT subject are the design appreciation, technology application, product creation, and product design evaluation (DSKP RBT form 3, 2017).

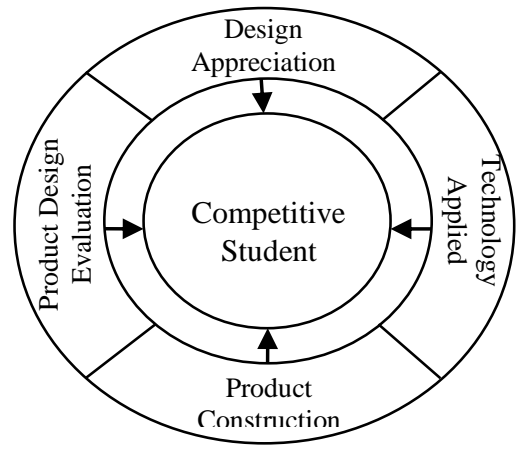

Figure 1; Design and Technology Domain
In this line, the ADDIE model which comprises of five main phases of analysis, design, development, implementation, and evaluation replicated perfectly the RBT's main learning domains. Furthermore, according to Dick, Carey, and Carey (2009), the design of an effective teaching and learning should include a systematic process of designing, developing, implementing, and evaluating the teaching itself. Hence, it is evident that the elements in the ADDIE model can work perfectly to complement the need to achieve the dominant RBT domains. Figure 2 shows the integration of ADDIE model in the process of developing modular teaching modules for applied topics in Design and Technology subject. Subsequent sections present a detailed discussion about the development of modular module based on ADDIE's model elements.

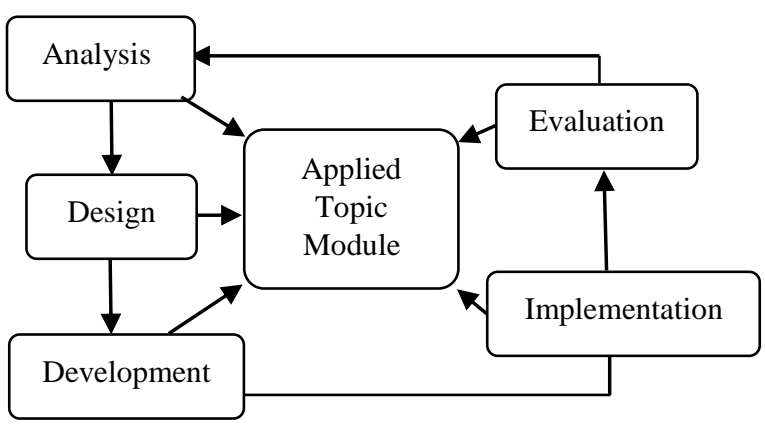

Figure 2; Modular Teaching Module Design based on ADDIE model

\section{$1 \quad$ Analysis}

According to the ADDIE model, the first step in developing modular modules is analysis. Analysis is a basic stage of achieving another step as analysis step aims to identify the topics to be taught, learning objectives to achieve, subject-content to be delivered, and suitability of target audience. Therefore, it is crucial to examine and identify students' prior knowledge skills as it helps in teachers pedagogical planning (Dick and Reiser, 1989).

In the context of Design and Technology subject (RBT), the analysis process that needs to be done involves four aspects:

- Analyse the existing knowledge and skills of students

- Analyse the standard content of the applied topics integrated in the curriculum standard (DSKP)

- Analyse the standard learning of the applied topics integrated in the curriculum standard (DSKP)

- Analyse the standard performance of the applied topics integrated in the curriculum standard (DSKP) 
Table 1: RBT Curriculum and Assessment Standard Documents Adaptation Form 1 till Form 3

\begin{tabular}{|c|c|c|}
\hline Form & $\begin{array}{l}\text { Standard applied } \\
\text { topics content }\end{array}$ & $\begin{array}{l}\text { Standard } \\
\text { performance } \\
\text { (Highest Level of } \\
\text { Mastery) }\end{array}$ \\
\hline 1 & $\begin{array}{l}\text { Fashion Design } \\
\text { Fertigation Design }\end{array}$ & $\begin{array}{l}\text { Create fashion } \\
\text { design } \\
\text { Create a mock-up } \\
\text { or a new model of } \\
\text { fertigation system }\end{array}$ \\
\hline 2 & $\begin{array}{l}\text { Develop } \\
\text { Technology } \\
\text { Mechanical Design } \\
\text { Electrical Design } \\
\text { Electronic Design } \\
\text { Aquaponics } \\
\text { System Design } \\
\text { Food Design }\end{array}$ & $\begin{array}{l}\text { Build and create } \\
\text { 3D model packs } \\
\text { Build functional } \\
\text { mechanical } \\
\text { gadgets } \\
\text { Build functional } \\
\text { electrical gadgets } \\
\text { Build electronic } \\
\text { circuit control } \\
\text { microcontroller } \\
\text { Generates } \\
\text { complete report of } \\
\text { an aquaponic } \\
\text { model } \\
\text { Produce food and } \\
\text { packaging design }\end{array}$ \\
\hline 3 & $\begin{array}{l}\text { Mechatronic } \\
\text { Design }\end{array}$ & $\begin{array}{l}\text { Make } \\
\text { modifications to } \\
\text { existing } \\
\text { mechatronic } \\
\text { products }\end{array}$ \\
\hline
\end{tabular}

Information on these four key aspects should be thoroughly analysed so that the data obtained can provide a basic idea in planning the next step. A point to note, this initial analysis stage can also include analysis of needs, goals, as well as task analysis (G. Muruganantham, 2015). Some of the sample questions that could potential help in gathering information on abovementioned aspects are:

- What level of students will be using this modular module?

- What are the existing skills and skills students have before using this modular module?

- Based on the students' varied abilities, what are the appropriate content standards that should be integrated?

- How can a knowledge breakdown and skills in learning standards be created?

- What activities can be implemented to achieve the highest level of performance standards?

- What is the appropriate problem statement for the topic that has been merged?
- What are the situations and challenges design that students need to produce?

- How can a teaching methodology be used to deliver the lesson effectively?

- How do students' growth assessment can be created?

This question needs to be analysed critically and comprehensively so that the resulting modular modules could ultimately benefit the teachers in the teaching of RBT subjects. The division of knowledge and skills should be based on the curriculum (DSKP) that has been developed by the Curriculum Development Division.

\subsection{Design}

Design is the second step after the analysis process step. The purpose of this second step is to develop an appropriate instructional method to achieve the objectives of the RBT subject. Planning and deciding on the appropriate design of pedagogical approach is essential as the formulation of the curriculum covers not only the content of the curriculum, the topics included in each subject, and the teaching materials, but it also includes the teaching and learning strategies (Nicholls \& Nicholls, 1978).

A point to highlight, the success of the students in achieving the goal of design subjects are mainly through inquiry, analysis, idea development, finding solutions, and evaluating process (International Baccalaureate Organization, 2014). Therefore, in developing this modular module, it is important for researcher to integrate these processes to ensure successful and meaningful learning. Back to this current study, the process of designing modular teaching modules for RBT, can be divided into four main elements to answer the standard content of the subject. These elements are knowledge facts, creation of ideas, product development, and product evaluation. Table 2 shows the learning standard and the proposal for allocation of modular learning phase.

In addition to the four modular learning elements, the next step is to compile the topics that are related. At this stage, teachers need to be wise in choosing the topics that will be in the form of modular and most importantly, the topics chosen should be suitable with the students' daily lifestyle and environment. 
Table 2: Electronic Design Topic Adaptation DSKP RBT, Form 2

\begin{tabular}{|c|c|c|}
\hline $\begin{array}{l}\text { Standard } \\
\text { Content }\end{array}$ & $\begin{array}{l}\text { Modular } \\
\text { Learning } \\
\text { Elements }\end{array}$ & Learning Standard \\
\hline \multirow{4}{*}{$\begin{array}{l}\text { Electronic } \\
\text { Design }\end{array}$} & $\begin{array}{l}\text { Knowledge } \\
\text { Facts }\end{array}$ & $\begin{array}{l}\text { 2.4.1 State the } \\
\text { definition } \\
\text { microcontroller } \\
2.4 .2 \text { Describe the } \\
\text { parts contained in a } \\
\text { microcontroller }\end{array}$ \\
\hline & $\begin{array}{l}\text { Idea } \\
\text { Formation }\end{array}$ & $\begin{array}{l}2.4 .3 \text { Generate } \\
\text { sketch of electronic } \\
\text { circuit design } \\
2.4 .4 \text { Build } \\
\text { functional simulation } \\
\text { circuit }\end{array}$ \\
\hline & $\begin{array}{l}\text { Product } \\
\text { Development }\end{array}$ & $\begin{array}{l}\text { 2.4.5 Connecting the } \\
\text { input circuit and the } \\
\text { output circuit to the } \\
\text { microcontroller } \\
\text { 2.4.6 Write } \\
\text { simplified } \\
\text { programming }\end{array}$ \\
\hline & $\begin{array}{l}\text { Product } \\
\text { Evaluation }\end{array}$ & $\begin{array}{l}2.4 .7 \text { Conduct the } \\
\text { testing and evaluation } \\
\text { of electronic circuit } \\
\text { functionality } \\
2.4 .8 \text { Recommend } \\
\text { improvements on the } \\
\text { electronic circuit } \\
\text { design }\end{array}$ \\
\hline
\end{tabular}

Furthermore, the level of the students' prior knowledge should also be taken into consideration and the educational materials should be creatively and systematically organized in accordance to the intellectual and physical development of the students (Mok Soon Sang, 2008).

\subsection{Development}

This step will lead to the details in the development of modular learning modules of RBT subjects. The modular system considers the differences in students' learning ability. Students who are less intelligent if given a longer learning time or duration should be able to achieve the level of the identified competence (Ahmad Tajudin Jab, 2005). Therefore, this development process should be clear in terms of:

1. Topic for a combination of selected standard content

2. Problem statements that need to be resolved

3. Learning objectives through the modular learning phase

4. Situation and task design project

5. Content required to complete the assignment

6. Proposed learning process to achieve objectives
Table 3 shows the initial framework of the modular module that focuses on students' understanding of the objectives and tasks to be conducted. As RBT stresses on experiential learning, it is important for students' to be self-driven. In this same vein, Ahmad Johari Sihes (2008) confidently suggested that learning will be so much is easier when someone is interested and willing to learn something. To spark students' interest and motivation, the combined applied topics needs to be clarified, the design task that needs to be solved should be explained, and the required information needed to achieve that goal need to be known by the students.

Table 3: Unit planner design guide adaptation, MYP IB

\begin{tabular}{|l|l|}
\hline $\begin{array}{l}\text { Unit } \\
\text { Topic }\end{array}$ & Young Inventor \\
\hline $\begin{array}{l}\text { Combined } \\
\text { standard } \\
\text { contents }\end{array}$ & $\begin{array}{l}\text { Mechanical Design and Electronic } \\
\text { Design }\end{array}$ \\
\hline $\begin{array}{l}\text { Problem } \\
\text { Statement }\end{array}$ & $\begin{array}{l}\text { Methods needed to create products in } \\
\text { the today's digital world depend on } \\
\text { the scientific, electronic and } \\
\text { mechanical processes. }\end{array}$ \\
\hline $\begin{array}{l}\text { Situation } \\
\text { and Task } \\
\text { Design }\end{array}$ & $\begin{array}{l}\text { Your school is chosen to participate } \\
\text { in a state-level robotic competition. } \\
\text { the project, conduct a preliminary } \\
\text { study on the product's market, and } \\
\text { build a suitable project for the } \\
\text { competition }\end{array}$ \\
\hline
\end{tabular}

The preparation of the teaching aids also plays a vital role in designing the modular module. The use of technology-based teaching aids can be practiced to increase the effectiveness of teaching and learning (Kamarul Azmi and Ab. Halim, 2007). In this regard, the development of modules should use illustrated and animated examples, structured work steps, online support system, video on the demonstration, and clear assessment rubrics published online for students references.

\subsection{Implementation}

Implementation step refers to the act of using modular teaching modules for RBT subject in the classroom. The purpose of implementing or carrying out the RBT module is to evaluate the effectiveness as well as the feasibility of the RBT modular module. The research methods appropriate for the implementation of this module as suggested by this study are the experimentation design which consists of control and treatment groups. The control group should use conventional or common teaching and learning methods. While the treatment group should use modular learning modules. The experimental research design is good at explaining a phenomenon associated with the cause and effect clearly by selecting two independent groups with 
the hypotheses stating that both groups have the same characteristics (Mohamad Najib Abdul Ghafar, 1999).

It is suggested that the selection of the control and treatment groups is by using random group sampling. The main features of the samples must be identified first so that the data that will be extracted later will have a high validity. Samples chosen should consist of teachers and students who have the following characteristics:

1. Characteristics of teacher group

a) Teaching RBT subjects

b) Teaching at the same level or form

2. Characteristics of the student group

a) Enroll in the RBT subject

b) In the same form or the same age

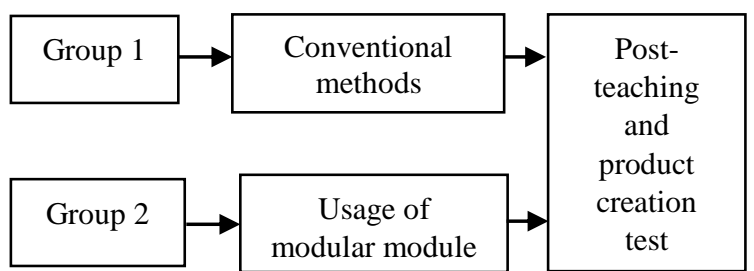

Figure 3: Implementation structure of the module

Teachers who are in the treatment group will be briefed on how to implement teaching and learning using the modular modules. The main thing that needs to be highlighted is that the practical method of producing the product and the procedure of collecting the evidence of the learning process that the student is executing. It is very important to observe the students' on-going learning process to determine the students' achievement rather than solely focus on the outcome of the final product (Malaysia Education Blueprint 2013-2025).

\subsection{Evaluation}

The evaluation step is the final step to obtain feedback on the usage of the modular module. Evaluation step is also important in determining the students' learning progress as well as understanding of the knowledge, tasks, and the quality of the project outcomes. Formative assessment should be done in every phases and summative assessments must be conducted at the end of the learning process by evaluating the project output (Baharudin Aris et al., 2000).

This current study suggested that an informal formative evaluation through depth and focused-group interview and analysis of the student paperwork are better able to provide sufficient and rich feedback on the extent the students understand and experience the modular module. As for the teacher, informal formative evaluation can provide extensive information on criteria or strategies needed for successful teaching (Noraini Idris, 2005). Figure 4 shows the evaluation framework suggested for later study.

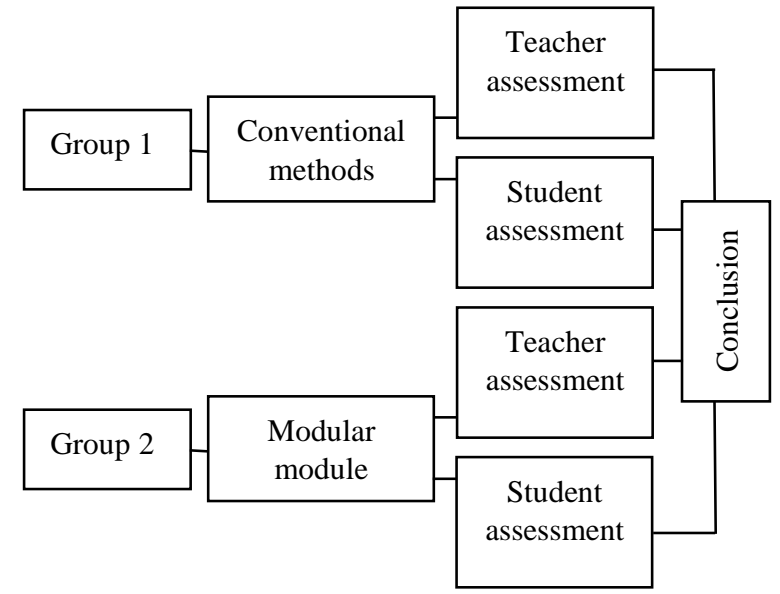

Figure 4: Evaluation Framework

To evaluate the teachers' conventional and modular teaching, some important points that need to be taken into considerations are:

- Duration of teaching time

- Provision of teaching aids

- Preparation of lesson plans

- Cost involved

The information gained from this evaluation step is essential to revised and improved the prototype modular module. Student's input which are crucial and needed to be explore include:

- Understanding the problem statement

- Understanding tasks based on topics

- Understanding the knowledge and skills acquired

- Evaluation of the resulted product

- Constraints in preparing the final project of each topic

- Cost involved

\section{CONCLUSION}

From the above discussion, the usage of the ADDIE model can be applied in the preparation of modular teaching modules for RBT subjects. This is demonstrated at each phase of structured and systematic analysis, design, development, implementation, and evaluation. Each phase provides an output that can be used as preliminary information to proceed to the next phase.

Through this paper, the information gathered can be used as a modular design guide by using the ADDIE model. The design and development phase in the model is very much in line with the standard content of the applied topics of the Design and Technology subject. Hence, coinciding with the objective of RBT subjects, the ADDIE model can be the foundation of designing a 
teaching module that will help teachers and students understand the knowledge and skills more efficiently.

\section{REFERENCES}

A. Nicholls \& SH. Nicholls, 1978. Developing a curriculum: a practical guide. George Allen and Unwin LTD. London.

Ahmad Johari Sihes, 2008. Psikologi Pendidikan: Konsep pembelajaran. Penerbit UTM. Skudai.

Ahmad Tajudin Jab, 2005. Panduan Ringkas: Pembangunan Kurikulum Teknikal dan Vokasional. Jabatan Pendidikan Teknikal, Kementerian Pendidikan Malaysia.

Baharudin Aris et al., 2000. Teknologi Pendidikan: Dari yang radisi kepada yang terkini. Jabatan Multimedia Pendidikan, UTM. Skudai.

Dick \& Reiser, 1989. Planning Effective Instruction, United States: Prentice Hall.

Dick, Carey, \& Carey, 2009. The Systematic Design of Instruction ( $7^{\text {th }}$ ed). Upper Saddle River, NJ: Pearson Education.

Dokumen Standard Kurikulum dan Pentaksiran mata pelajaran Reka Bentuk dan Teknologi Tingkatan 3, 2017. Bahagian Pembangunan Kurikulum, Putrajaya.

G. Muruganantham, 2015. Developing of E-content Package by sing ADDIE Model. International Journal of Applied Research. India.

KamarulAzmi \& Ab. Halim Tamuri, 2007. Pendidikan Islam Kaedah Pengajaran dan Pembelajaran. Penerbit UTM. Skudai, Johor.

Mia Bullock, 2015. What Make a Good Teacher? St. Mary's College of Maryland.

Stenhouse, 1975. Introduction to Curriculum Research and Development. Lynne Rienner Publishers. United States

Mohamad Najib Abdul Ghafar, 1999. Penyelidikan Pendidikan. Penerbit UTM. Skudai.

Mok Soon Sang, 2008. Pengurusan Kurikulum. Penerbitan Multimedia Sdn.Bhd. Selangor.

Noraini Idris, 2005. Pedagogi Dalam Pendidikan matematik. Utusan Publication \& Distributor Sd. Bhd. Kuala Lumpur.

Yusup Hashim, 2006. Teknologi Intrusktional: Teori dan Aplikasi. Tanjung Malim.

Pendekatan Modular Dalam Pengajaran dan Pembelajaran. 2010. Bahagian Pembangunan Kurikulum KPM.

Design Book, 2014. International Baccalaureate Organization.

Dokumen Standard Kurikulum dan Pentaksiran mata pelajaran Reka Bentuk dan Teknologi Tingkatan 2, 2016. Bahagian Pembangunan Kurikulum, Putrajaya.

Dokumen Standard Kurikulum dan Pentaksiran mata pelajaran Reka Bentuk dan Teknologi Tingkatan
3, 2017. Bahagian Pembangunan Kurikulum, Putrajaya.

Pelan Pembangunan Pendidikan Malaysia, 2013-2025 